\title{
Sewage sludge gasification process for clean and sustainable environment
}

\author{
Sebastian Werle* \\ Institute of Thermal Technology, Silesian University of Technology, Gliwice, Poland
}

\begin{abstract}
This work presents a multicriterial investigation of the sewage sludge gasification in the fixed bed gasifier. The operating parameters of gasification were varied over a wide range. Parameters such as air ratio $\lambda=0.12-0.27$, gasification agent preheating $t=50-250{ }^{\circ} \mathrm{C}$ and gasification agent composition $\left(z_{\mathrm{O}_{2}}=0.21\right.$ and $\left.z_{\mathrm{O}_{2}}>0.21\right)$ were found to influence syngas lower heating value and syngas composition.
\end{abstract}

\section{Introduction}

The quantity of sludge production in Europe [1-4] varies widely over different countries (16-94 g/(person day)). Moreover, the final of sewage sludge disposal depends on the sludge treatment methods used on the wastewater treatment plant.

Sewage sludge is a solid, semisolid, or liquid residue that results after the treatment process of waste water. Sewage sludge is an example of the biomass feedstock [5]. The composition of the organic fraction in biomass doesn't vary much. However, the variation of the moisture and ash content is large [6-8]. The most popular way of final sewage sludge management is storage. In countries that are technologically less developed, direct agricultural application or storage is typical pathways to safely dispose of stabilized sludge from wastewater treatment plants. In countries where policy makers practically forbade such solutions (e.g., the European Union), only thermal disposal methods are available [9-12]. The thermo-chemical conversion of sewage sludge consists of four main processes: combustion, co-combustion, pyrolysis and gasification. One of the promising thermo-chemical conversion technologies that can be used to convert sewage sludge to useful energy forms is gasification. This process has several advantages over a traditional combustion process [13]. First of all, as a consequence of the reducing atmosphere in the gasifier, gasification prevents emissions of sulphur and nitrogen oxides, heavy metals and the potential production of chlorinated dibenzodioxins and dibenzofurans. Due to it most of sulphur, nitrogen, chloride and fluoride in sewage sludge may be released as $\mathrm{H}_{2} \mathrm{~S}, \mathrm{NH}_{3}, \mathrm{HCl}$ and $\mathrm{HF}$. Secondly, a less volume of gas is produced compared to the volume of flue gas from combustion [14-20].

\footnotetext{
* e-mail: sebastian.werle@polsl.pl
}

This article reports on experimental investigations of fixed-bed gasification of sewage sludge. The operating parameters of gasification were varied over a wide range. Parameters such as air ratio $\lambda=0.12-0.27$, gasification agent preheating $t=50-250{ }^{\circ} \mathrm{C}$ and gasification agent composition $\left(z_{\mathrm{O}_{2}}=0.21\right.$ and $\left.z_{\mathrm{O}_{2}}>0.21\right)$ were found to influence syngas lower heating value (LHV) and syngas composition.

\section{Experimental}

\subsection{Apparatus}

The current study was conducted using a fixed bed gasification which was described earlier [21]. A scheme of the facility is shown in Figure 1.

The granulated sewage sludge was fed into the reactor. After approximately $120 \mathrm{~min}$, the reactor was heated. The gasification cold air and preheated air flow rate/enriched air flow rate to the reactor was adjusted to ensure a specified air ratio. Once producer gas production began, the measurements of key parameters were started. As the sewage sludge was gasified, the ash produced was gradually discharged from the bed. The bed was maintained at a constant height by the addition of fuel at regular time intervals. A fraction of the gases produced during gasification was first passed through a condensing system which condensed out the condensables, followed by a set of filters for particulate removal to allow clean gas to enter the gas analyzer. Representative gas samples were also collected in Tedlar $^{\circledR}$ gas bags for off-line measurements. The gases were subsequently analyzed using a chromatograph. The same procedure was repeated at different air ratios. Uncertainty in the measurements might have arisen from errors in the mass balances and volumetric apparatuses. 


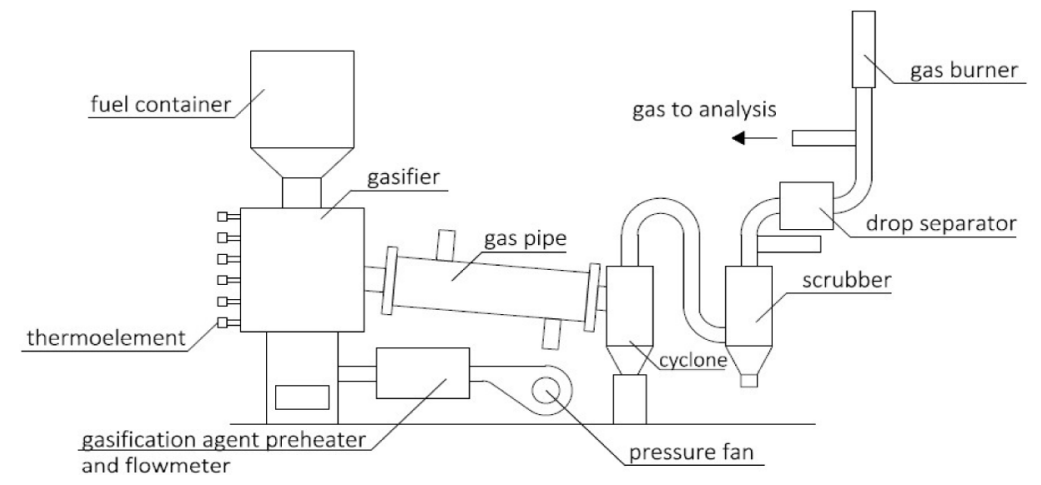

Fig. 1. Scheme of the experimental system.

\subsection{Fuel properties}

Two types of sewage sludge feedstock were analyzed.

Sewage sludge No. 1 (SS1) was taken from wastewater treatment plant operating in the mechanical-biological system and sewage sludge No. 2 (SS2) was taken from mechanical-biological-chemical wastewater treatment plant with phosphorus precipitation. In both analyzed cases, biological part of the wastewater treatment plant has worked with low load activated sludge. Thanks to it, effective removal of nutrients (phosphorus and nitrogen) from wastewaters is allowed. Additionally, in both analyses cases, sewage sludge is stabilized by anaerobic digestion and dehydration. After it, sewage sludge is dried. In the case 1 (SS1) sewage sludge was dried in cylindrical dryer with heated shelf. The temperature of hot air was equal to $260{ }^{\circ} \mathrm{C}$ (high temperature). In the case 2 (SS2) air belt dryer was used. The temperature of hot air in this case was equal to $150^{\circ} \mathrm{C}$ (low temperature). As a consequence, in the case 1 form of the dried sludge is similar to granulate and in the case 2 to "noodles". Table 1 reports the properties of the analyzed sewage sludge.

\section{Result and discussion}

\subsection{Influence of the air ratio on the composition of syngas}

Figure 2 shows the evolution of the $\mathrm{H}_{2}, \mathrm{CO}, \mathrm{CO}_{2}$ and $\mathrm{CH}_{4}$ concentrations in gasification gas with varying air ratios for both analyzed sludge. Air ratio is a parameter that quantifies the amount of air/oxygen per unit mass of fuel, as compared to the theoretical amount of air/oxygen needed for complete combustion. Hence, the optimum air ratio that favors gasification resulting in combustible gases like $\mathrm{CO}$, rather than the case of complete combustion with an air supply that mainly produces $\mathrm{CO}_{2}$ need to be determined. In this study, a number of gasification experiments were done by varying the air ratio from 0.12 to 0.27 . Analyzing Figure 2, it can be confirmed that throughout the range of analyzed air ratio volumetric fraction of main combustible components of gasification gas $\left(\mathrm{CO}\right.$ and $\left.\mathrm{H}_{2}\right)$ are higher in the case of the SS1 in comparison to SS2. At lower values of air ratio CO composition was found to be low and it starts to rise until
Table 1. Properties of the fuel tested.

\begin{tabular}{|c|c|c|}
\hline Parameters & SS1 & $\mathrm{SS} 2$ \\
\hline \multicolumn{3}{|c|}{ Proximate analysis, \% (as received) } \\
\hline Moisture & 5.30 & 5.30 \\
\hline Volatile matter & 44.20 & 36.50 \\
\hline Ash & 49.00 & 51.50 \\
\hline \multicolumn{3}{|c|}{ Ultimate analysis, \% (dry basis) } \\
\hline $\mathrm{C}$ & 27.72 & 31.79 \\
\hline $\mathrm{H}$ & 3.81 & 4.36 \\
\hline $\mathrm{O}$ & 3.59 & 4.88 \\
\hline $\mathrm{N}$ & 13.53 & 15.27 \\
\hline S & 1.81 & 1.67 \\
\hline $\mathrm{F}$ & 0.003 & 0.013 \\
\hline $\mathrm{Cl}$ & 0.033 & 0.022 \\
\hline $\mathrm{LHV}, \mathrm{kJ} / \mathrm{kg}$ dry basis & 10,747 & 12,962 \\
\hline $\begin{array}{l}\text { The sum of the PAHs, } \\
\mu \mathrm{g} / \mathrm{kg} \text { dry basis }\end{array}$ & 2433.40 & 621.33 \\
\hline $\begin{array}{l}\text { The sum of the } \\
\text { pesticides, } \mu \mathrm{g} / \mathrm{kg} \text { dry basis }\end{array}$ & 18.85 & 1.28 \\
\hline $\begin{array}{l}\text { The sum of the PCBs, } \\
\mu \mathrm{g} / \mathrm{kg} \text { dry basis }\end{array}$ & 66.86 & 12.47 \\
\hline \multicolumn{3}{|c|}{ Heavy metals, mg/kg dry basis } \\
\hline $\mathrm{Zn}$ & 920.90 & 991.20 \\
\hline $\mathrm{Cu}$ & 495.30 & 183.16 \\
\hline $\mathrm{Pb}$ & 119.30 & 59.97 \\
\hline $\mathrm{Ni}$ & 103.67 & 18.90 \\
\hline $\mathrm{Cr}$ & 180.53 & 584.53 \\
\hline $\mathrm{Cd}$ & 6.47 & 3.24 \\
\hline As & 4.19 & 3.94 \\
\hline $\mathrm{Hg}$ & 0.99 & 0.96 \\
\hline $\mathrm{Se}$ & 9.84 & 1.70 \\
\hline Sum & 1841.19 & 1847.60 \\
\hline
\end{tabular}

the optimum air ratio of 0.18 and later drops for higher equivalence ratio. The maximum $\mathrm{CO}$ average composition values of $31.3 \%$ for SS1 (and $26.9 \%$ for SS2) were obtained for gasification at $\lambda=0.18 . \mathrm{CO}_{2}$ shows an inverse relation 

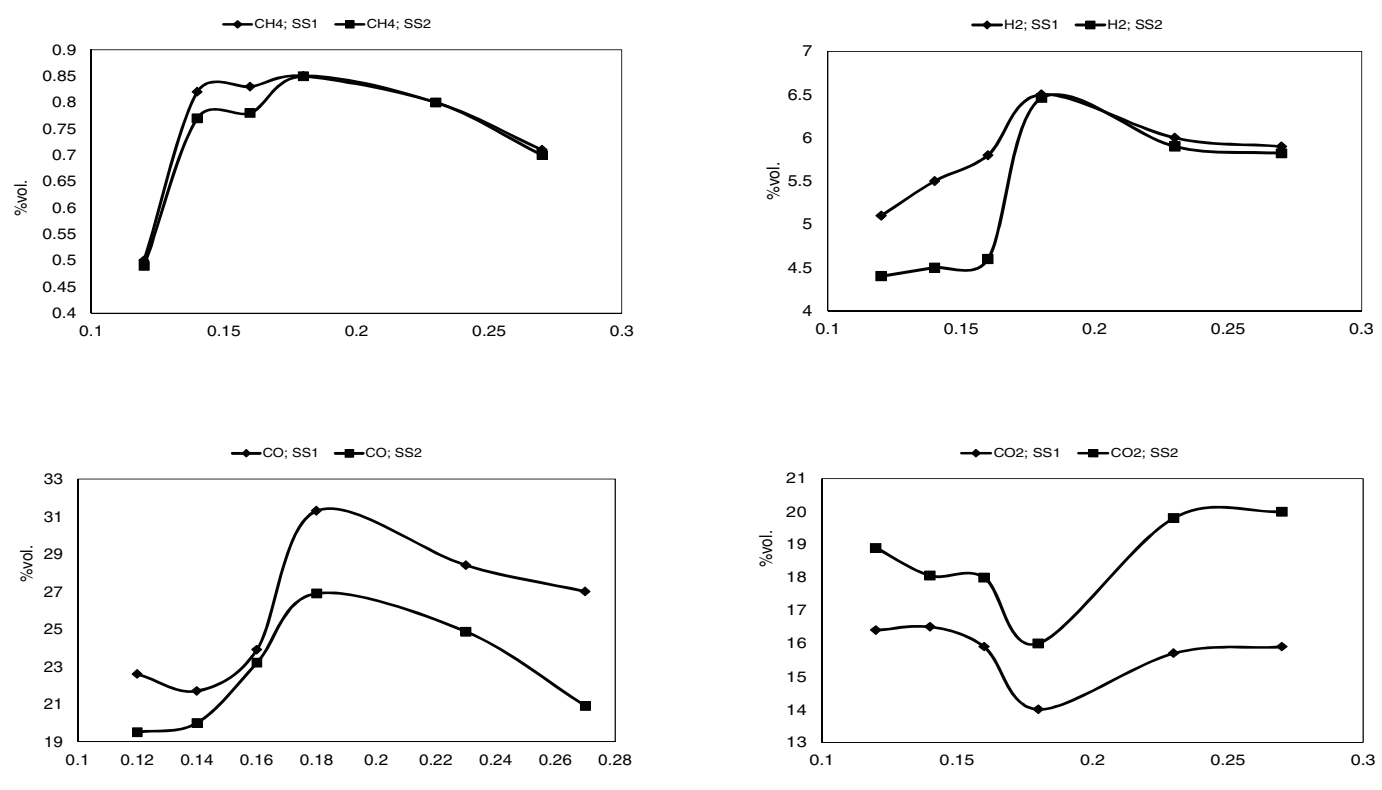

Fig. 2. Evolution of the main components in sewage sludge gasification gas as a function of the air ratio.

with $\mathrm{CO}$ as the reactions that produce those gases are competing for the same reactants namely carbon. The concentration of carbon dioxide is generally expected to be minimum of the optimal air ratio range between 0.18 and 0.24. Rapid growth of CO observed in the value of the air ratio equal to 0.18 is caused by the dominant role of the primary water gas reaction. The reactions that can occur in the gasifier as a result of the gasification agent flow can be categorized as a the reaction of gasification agent and carbon in the fuel and the reaction of gasification agent and $\mathrm{CO}$ in the gas. The reaction of gasification air and carbon is an endothermic reaction that generates mainly $\mathrm{CO}$ whereas the reaction of gasification air and $\mathrm{CO}$ is an exothermic reaction that generates mainly $\mathrm{CO}_{2}$ (and $\mathrm{H}_{2}$ ). When gasification air is fed with the fuel into the reactor, the endothermic reaction of air and carbon occurs first (e.g. primary water gas reaction $\mathrm{CO}+\mathrm{H}_{2} \mathrm{O} \rightarrow \mathrm{CO}+\mathrm{H}_{2}$ ), and the $\mathrm{CO}$ in a gaseous state produced from the fuel reacts with the residuals causing next reactions (e.g. water gas shift $\mathrm{CO}+\mathrm{H}_{2} \mathrm{O} \leftrightarrow \mathrm{CO}_{2}+\mathrm{H}_{2}$ ). Thus, the composition of $\mathrm{H}_{2}$, $\mathrm{CO}$ and $\mathrm{CO}_{2}$ in the gasification gas changes according to the amount of the air supplied to the reactor.

In Figure 3, the dependence of LHV of obtaining gas versus an air ratio is presented.

The LHV in $\mathrm{MJ} / \mathrm{m}^{3} \mathrm{n}$ of the syngas was estimated using the formula given below [22]:

$$
\mathrm{LHV}=0.126 \cdot \mathrm{CO} 0.108 \cdot \mathrm{H}_{2} 0.358 \cdot \mathrm{CH}_{4} \text {. }
$$

Analyzing this figure, it can be concluded that taking into consideration the LHV of the gasification gas there is the optimum value of the air ratio equal to 0.18 in which the LHV takes its maximum value. It is true irrespective of the sewage sludge type. Above that optimal value, the thermo-chemical process could be shifted from gasification to combustion.

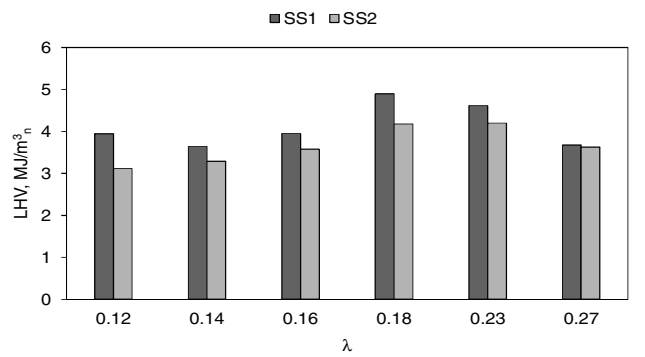

Fig. 3. LHV of the gasification gas versus air ratio.

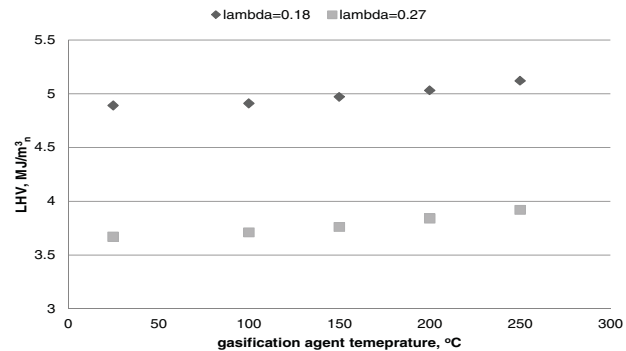

Fig. 4. Influence of the gasification agent temperature on the LHV of the syngas.

\subsection{Influence of the temperature of gasification agent on syngas composition}

Figure 4 demonstrates that the use of hot air for sewage sludge gasification was able to produce gasification gas with a superior heating value compared to low temperature gasifiers, which produce producer gas with LHVs ranging up $5.12 \mathrm{MJ} / \mathrm{m}^{3} \mathrm{n}$.

It is caused by the increment of the yield of the main producer gas components, $\mathrm{CO}, \mathrm{H}_{2}$ and $\mathrm{CH}_{4}$, which were enhanced by increasing the gasification agent 


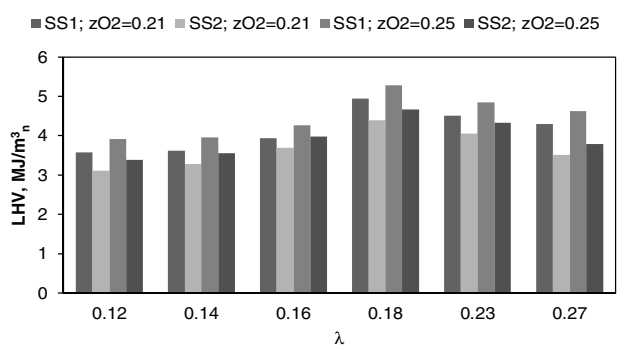

Fig. 5. Influence of the gasification composition on the syngas LHV.

temperature. This is mainly due to the involved endothermic reactions in the gasification process which become more dominant at higher temperatures. Similar behavior is also found during catalytic gasification. The high temperature of gasification agent was sufficient to allow for secondary thermocracking reactions that increased the producer gas yield.

\subsection{Influence of the gasification agent composition on syngas composition}

Figure 5 shows the influence of the gasification agent composition on the LHV of producing gas. The gasification agent studied is composed of nitrogen and oxygen mixtures. The oxygen molar concentration studied were equal to: $21 \%$ and 25\%. Analyzing Figure 5, it concludes that LHV of the producer gas slightly increases with the increment of the oxygen concentration in gasification agent. This is mainly caused by the lower dilution by the nitrogen.

\section{Conclusions}

The main conclusions from the study are as follows:

- The operating conditions (amount of the gasification agent) of the sewage sludge gasification process greatly influence the syngas composition distribution.

- Higher values of the main components (especially $\mathrm{C}$ and $\mathrm{H}$ ) in the sewage sludge plant affect on the increase of the LHV of gasification gas.

- Throughout the range of analyzed air ratio $(\lambda=0.12$ -0.27 ) volumetric fraction of main combustible components of gasification gas $\left(\mathrm{CO}\right.$ and $\left.\mathrm{H}_{2}\right)$ are higher in the case of the SS1 in comparison to SS2.

- Taking into consideration the LHV of the gasification gas, there is the optimum value of the air ratio equal to 0.18 in which the LHV takes its maximum value. It is true irrespective of the sewage sludge type.

- The yield of the main producer gas components, CO, $\mathrm{H}_{2}$ and $\mathrm{CH}_{4}$, was enhanced by increasing the gasification agent temperature and increasing of the oxygen concentration in the gasification agent.

The paper has been prepared within the frame of the National Science Centre project based on decision no DEC-2011/03/D/ ST8/04035.

\section{References}

1. Y. Cao, A. Pawłowski, Sewage sludge-to-energy approaches based on anaerobic digestion and pyrolysis: brief overview and energy efficiency assessment, Renew. Sust. Energy Rev. 16, 1657 (2012)

2. A. Kelessidis, A.S. Stasinakis, Comparative study of the methods used for treatment and final disposal of sewage sludge in European countries, Waste Manag. 32, $1186(2012)$

3. S. Werle, Modeling of the reburning process using sewage sludge-derived syngas, Waste Manag. 32, 753 (2012)

4. S. Werle, A reburning process using sewage sludge-derived syngas, Chem Pap. 66, 99 (2012)

5. K.J. Ptasinski, M.J. Prins, A. Pierik, Exergetic evaluation of biomass gasification, Energy 32, 568 (2007)

6. D.W. Van Krevelen, J. Schuyer, Coal Science (Elsevier Publishing Company, Amsterdam, the Netherlands, 1957)

7. J.W. Judex, M. Gaiffi, H.Ch. Burgbacher, Gasification of dried sewage sludge: status of the demonstration and the pilot plant, Waste Manag. 32, 719 (2012)

8. S.-W. Park, Ch.-H. Jang, Characteristics of carbonized sludge for co-combustion in pulverized coal power plants, Waste Manag. 31, 523 (2011).

9. Commission of European Communities, Council Directive 91/271/EEC of 21 March 1991 concerning urban wastewater treatment (amended by the $98 / 15$ EC of 27 February 1998)

10. Commission of European Communities, Council Directive $86 / 278 /$ EEC of 4 July 1986 on the protection of the environment and in particular of the soil, when sewage sludge is used in agriculture

11. Commission of European Communities, Council Directive 91/156/EEC of March 1991 amending Directive 75/442/ EEC on waste

12. Commission of European Communities, Council Directive 99/31/EC of 26 April 1999 on the landfill of waste

13. L.E. Taba, M.F. Irfan, W.A.M.W. Daud, M.H. Chakrabarti, The effect of temperature on various parameters in coal, biomass and $\mathrm{CO}$ - gasification: a review, Renew. Sust. Energy Rev. 16, 5584 (2012)

14. J.C. Buckley, P.M. Schwarz, Renewable energy from gasification of manure: an innovative technology in search of fertile policy, Environ. Monit. Assess. 84, 111 (2003)

15. J. Chang, Y. Fu, Z. Luo, Experimental study for dimethyl ether production from biomass gasification and simulation on dimethyl ether production, Biomass Bioenergy 39, 67 (2012)

16. N. Kobayashi, M. Tanaka, G. Piao, J. Kobayashi, S. Hatano, Y. Itaya, S. Mori, High temperature air-blown woody biomass gasification model for estimation of an entrained down-flow gasifier, Waste Manag. 29, 245 (2009)

17. T.W. Marrero, B.P. McAuley, W.R. Sutterlin, J.S. Morris, S.E. Manahan, Fate of heavy metals and radioactive metals in gasification of sewage sludge, Waste Manag. 24, 193 (2012)

18. F. Pinto, H. Lopes, R.N. Andre, M. Disa, I. Gulyurtlu, I. Cabrita, Effect of experimental conditions on gas quality and solids produced by sewage sludge cogasification, Energy Fuel 21, 2737 (2007) 
19. S.S. Thanapal, K. Annamalai, J.M. Sweeten, G. Gordillo, Fixed bed gasification of dairy biomass with enriched air mixture, Appl. Energy 97, 525 (2012)

20. S. Werle, R.K. Wilk, A review of methods for the thermal utilization of sewage sludge: the Polish perspective, Renew. Energy 35, 1914 (2010)
21. S. Werle, Possibility of $\mathrm{NO}_{x}$ emission reduction from combustion process using sewage sludge gasification gas as an additional fuel, Arch. Environ. Prot. 38, 81 (2012)

22. J.W. Kim, T.Y. Mun, J.O. Kim, J.S. Kim, Air gasification of mixed plastic wastes using a two-stage gasifier for the production of producer gas with low tar and high caloric value, Fuel 90, 2266 (2011)

Cite this article as: Sebastian Werle, Sewage sludge gasification process for clean and sustainable environment, Renew. Energy Environ. Sustain. 1, 35 (2016) 